\title{
Ensaio
}

\section{O guia}

\author{
Viriato João Leal da Cunha
}

1. Professor do Departamento de Cirurgia, Centro de Ciências da Saúde, Universidade Federal de Santa Catarina

DOI: https://doi.org/10.32963/bcmufsc.v6i1.4162

e-mail: viriatocunha@hotmail.com

Em 25 de maio de 2020,67 dia de isolamento.

Desde menino, sempre que passava à frente de um Hospital via ali o meu destino. Não sei se o desejo de ser médico nasceu comigo, ou foi plantado junto com o carinho e o amor com que meus pais me criaram. Aprendi, provavelmente com eles, a admirar essa carreira. Mais que uma profissão, uma dedicação de vida inteira.

Do Hospital de Caridade ouvia muitas histórias sobre médicos famosos, bondosos e dedicados. Dr. Ney Mund era um dos destaques, tratou meu pai de uma úlcera péptica hemorrágica. Gratidão devotada a ele, sempre havia em minha casa.

Era uma época onde os médicos atendiam em domicílio. Recebemos muitas vezes a visita de nosso pediatra, Dr. Gabriel Faraco. Competente e dedicado, com uma calma singular, trazia em sua valise preta, além dos aparelhos para avaliação clínica e o receituário, grande dose de carinho a distribuir aos pequenos pacientes, e muita confiança a transmitir às suas mães.

Além desses médicos, meu pai sempre mencionava grandes nomes da época e do passado, que eu não conhecia, mas aprendi através dele a admirar. Cirurgiões eram sua preferência, como Dr. Richard Gottsmann e Dr. Roldão Consoni, dentre outros. Mas um sempre era lembrado, com especial admiração, Ernesto Damerau. Geralmente dito assim, sem o doutor. Com a intimidade que os hábitos simples desta nossa terra dedicam às pessoas merecedoras de grande gratidão. Ouvi falar muito dele, sempre em comentários que ressaltavam, além de sua admirável habilidade técnica e conhecimento científico, qualidades humanas e éticas exemplares. Vi muitas vezes um brilho especial nos olhos daqueles que mencionavam seu nome. Sem mesmo o conhecer, ou ter visto algum retrato, acabei criando em torno dessa figura uma imagem de herói. Sentia isso desde aqueles tempos, mas só fui entender realmente esse significado mais tarde.

O tempo passou. Aprovado no vestibular para medicina, fui seguindo meu caminho. Lembro agora do primeiro dia em que entrei em um centro cirúrgico. Tinha concluído a terceira fase de medicina na UFSC. Havia cursado as matérias do módulo básico. Anatomia, histologia, fisiologia, dentre outras. Mas nada diretamente relacionado a pessoas. Pelo menos pessoas vivas à minha frente. Ânsia maior e precoce de todo aluno do curso médico. Até então eram só cadáveres, lâminas ao microscópio e animais de laboratório.

Criei essa oportunidade através de um médico conhecido, Roberto Teixeira. Jovem cirurgião vascular, respeitado em sua especialidade, tinha laços familiares com minha namorada, o que me permitia convívio frequente e a possibilidade de solicitar seu auxílio para visitar um centro cirúrgico. Solicitação acolhida, lá estava eu às 7:00h do dia seguinte, na Emergência do Hospital de Caridade, onde o Dr. Teixeira prestava atendimento diariamente.

Ansioso e preocupado com minha primeira incursão cirúrgica, passei a noite anterior estudando e treinando noções básicas para lavação das mãos, colocação de aventais e luvas estéreis. Havia retirado um livro de Técnica Operatória e Princípios de Cirurgia na Biblioteca da Faculdade de Medicina, localizada à rua Ferreira Lima. Busquei ler algo para me orientar. Sabia que meu desejo de ir ao hospital era um pouco precoce. Ainda não tinha frequentado as primeiras disciplinas das áreas clínicas ou cirúrgicas. Uma natural insegurança se apoderava dos meus pensamentos. Mas nada me afastaria de tão atraente oportunidade.

Chegou o esperado momento. Roberto Teixeira me levou ao Centro Cirúrgico, apresentou-me à Irmã Áurea, religiosa que chefiava o setor, com disciplina quase militar. Ela me entregou a roupa para trocar, gorro, máscara e propé, junto com várias recomendações comportamentais, sob olhar austero, 
mas ao mesmo tempo benevolente e acolhedor. Poucas pessoas conseguem associar essas características, típicas dos que detém uma natural capacidade de liderança. Naqueles tempos as freiras ocupavam os principais postos de enfermagem em vários hospitais.

Teixeira foi comigo ao vestiário, e chamou quem passaria a orientar minha primeira visita àquele desconhecido ambiente. Fui recebido por uma jovem simpática, de nome Avani, a qual me conduziu através de um corredor que levava a quatro salas cirúrgicas. Ao passar em frente a uma longa pia com várias torneiras, usada para lavação das mãos, vendo um cirurgião que se preparava para uma operação, não contive meu ímpeto apressado, e querendo justificar para mim mesmo o esforço dispendido durante a noite anterior, perguntei:

- Avani, já é agora que tenho de lavar as mãos e colocar as luvas?

- Como assim, mal acabastes de chegar e já queres entrar em campo ...? Respondeu-me com um sorriso amigável, mas demonstrando que eu havia dado meu primeiro fora. Típico de principiante afobado.

A jovem técnica de enfermagem levou-me calmamente até a sala de número três. Um quirófano de formato redondo, com ampla janela composta por vidros opacos, onde transcorria uma operação, que para mim parecia muito estranha. O paciente, homem de aspecto emagrecido, estava apenas sedado, por vezes gemendo baixinho, coberto por campos operatórios estéreis, os quais permitiam ver seu rosto com semblante de sofrimento.

Fui apresentado ao cirurgião, Dr. Ricardo Baratieri, que com breve olhar aceitou minha presença, e indicou o local de onde eu poderia assistir aos próximos passos daquela operação. Dr. Roberto Teixeira já tinha programado previamente com ele a minha visita.

Hábil e sereno, o cirurgião atuava através de uma abertura no abdome e removia um pequeno fragmento do fígado, que apresentava uma superfície nodular e aparentava ter consistência firme. Mais tarde fui saber que se tratava de um paciente com cirrose hepática, cujo diagnóstico etiológico dependia da realização de uma biópsia.

Imóvel durante todo o restante do ato operatório, permaneci em pé sobre uma pequena escada de metal, a uma distância do cirurgião suficiente apenas para não encostar nele. Tomado por um misto de satisfação e apreensão, assistia pela primeira vez uma operação. Estava sendo realizada uma biópsia hepática a céu aberto, sob anestesia local e sedação, devido ao grave estado clínico do paciente impedir anestesia geral - situação habitual para aqueles tempos, mas incomum nos dias de hoje.

Naquele momento, eu dedicava toda a minha atenção para entender cada passo operatório realizado. Estava sob concentração total, somente interrompida por ocasionais gemidos do paciente, que era acalmado por palavras de compaixão e apoio, proferidas pelo cirurgião, associadas a doses repetidas de analgésicos potentes e sedativos, administradas pelo anestesiologista.

Fiquei tão impressionado com a coragem e autoconfiança com que o jovem médico conduziu aquela operação, que ao final fui procurá-lo. Após uma breve conversa, perguntei ao Dr. Baratieri se eu poderia acompanhá-lo em outras cirurgias. Expus meu interesse por esta área, que apesar de precoce, já estava bem delineado.

- Muito bom seu interesse, - respondeu-me com entusiasmo, mas informando que por sua equipe estar completa, teríamos de pensar em outra alternativa. Senti que de alguma forma teria minha solicitação aceita. Após poucos instantes, em que vi em seu olhar a busca por uma opção, completou:

- Sei de um colega que pode assimilar você na equipe. Esteja aqui amanhã logo no início da manhã, que te apresentarei a ele.

Na manhã seguinte lá estava eu. Animado e confiante cheguei cedo, antes das 7:00h. Após aguardar um pouco, próximo a entrada do Centro Cirúrgico, vi o Dr. Baratieri vindo pelo longo corredor central do hospital, ao lado de outro médico. Era alto, magro, usava óculos, sorridente e brincalhão com os conhecidos que encontrava pelo caminho. Aparência simpática e acolhedora. Fui apresentado rapidamente.

- Dr. Damerau, este é o aluno indicado pelo Teixeira. Parece esperto...

Ao ouvir o nome do cirurgião que eu estava sendo indicado para acompanhar, fiquei sem fôlego. O Divino destino colocava à minha frente aquele que foi, para mim e para muitos outros médicos, mais que um mestre, um guia a iluminar nossa longa caminhada.

Que Deus o abençoe com a paz eterna. 